\title{
PENGARUH EFEKTIFITAS DAN PRODUKTIFITAS KERJA PRAMUSAJI TERHADAP PELAYANAN HOTEL DI JEMBER
}

\author{
Hadi Jatmiko \\ Prodi Perhotelan, FISIP Universitas Muhammadiyah Jember \\ Jl. Karimata No.49 Jember Kode Pos 69121 \\ Email : hadijatmiko@unmuhjember.ac.id
}

\begin{abstract}
Title of this research is the "Influence of Effectivityand Waiters'Working Productivity onHotelService In Jember".This research is to study and to determine the effect of waiter's effectivity and productivity in improving hotelservice in Jember being expected to generate information on the effectivity and productivity of food and beverage service in accordance with the guests wishes. To achieve these objectives, this research uses qualitative descriptive method. Respondents are the waters working at the hotel in Jember with the total number 95 respondents. Method of collecting data in this research uses the observation, structured interviews, literature study and questionnaire. Data analysis technique uses qualitative descriptive analysis, supported by statistical linearanalysis and testing of the hypothesis proposed research through F-test and T-test statistics.. Based on the results of data analysis and description of the discussion, it is concluded that the hotelwaiter / ss in Jember and labor productivity have significant influence on the quality of service in the hotel steward or waiter / ssin Jember.
\end{abstract}

Keywords : Effectiveness and Productivity, Waiter, Hotel Services

\begin{abstract}
ABSTRAK
Penelitian ini berjudul "Pengaruh Efektifitas Dan Produktifitas Kerja PramusajiTerhadap Pelayanan Hotel Di Jember". Penelitian ini mengkaji dan mengetahui pengaruh efektifitas dan produktifitas Pramusaji dalam meningkatkan pelayanan hotel di Jember yang diharapkan dapat menghasilkan informasi tentang Efektifitas dan Produktifitas pelayanan makanan dan minuman di hotel sesuai dengan keinginan tamu. Untuk mencapai tujuan tersebut, penelitian ini mengunakan metode deskriptif kualitatif. Dalam penelitian ini respondennya adalah Pramusaji yang berada di hotel di Jember sebanyak 95 responden. Teknik pengumpulan data dalam penelitian ini menggunakan metode observasi, wawancara berstruktur, studi kepustakaan dan kuesioner. Sedangkan teknik analisis data menggunakan analisis deskriptif kualitatif, dengan dukungan analisis statistik Linier Berganda dan Pengujian terhadap hipotesis penelitian yang diajukan melalui Uji F-Statistik dan Uji t-Statistik. Berdasarkan hasil analisis data serta uraian pembahasan diperoleh kesimpulan bahwa Efektifitas memiliki pengaruh signifikan terhadap kualitas layanan pramusaji atau waiter/ss hotel di Jember dan Produktifitas kerja memiliki pengaruh signifikan terhadap kualitas layanan pada Pramusaji atau waiter/ss hotel di Jember.
\end{abstract}

Kata kunci : Efektifitas dan Produktifitas, Pramusaji, Pelayanan Hotel 


\section{PENDAHULUAN}

Persaingan bisnis hotel di Indonesia semakin ketat dalam beberapa tahun terakhir, tidak terkecuali di Jember Jawa Timur. Satu sisi wisatawan semakin berpengalaman dan makin meningkat tuntutan terhadap pelayanan yang diingikannya. Pada saat yang bersamaan jumlah wisatawan Manca Negara masih belum pulih dengan adanya rentetan peristiwa internasional dan nasional yang saling silih berganti. Sementara di sisi lain, perusahaan hotel dan restaurant terus bertambah tidak hanya di kota-kota besar tetapi Jember sebagai kota kecil sudah di masuki banyak investor yang siap bersaing dengan hotel-hotel yang sudah lama berdiri di Jember.

Memahami pentingya keberadaan pramusaji sudah saatnya diperhatikan pentingnya memahami efektifitas dan produktifitas yang dihasilkan oleh Pramusaji atau Waiter/ss dalam memberikan pelayanan makanan dan minuman kepada tamu yang menginap. Efektifitas mengandung arti bahwa setiap pekerjaan dapat dilaksanakan secara efektif dengan menggunakan sumberdaya yang terbatas namun produktifitas hasil yang diinginkan dapat dipercaya oleh konsumen yang secara langsung menikmatinya. Dengan demikian, antara produktifitas dan efektifitas berjalan harus secara sistimatis dalam tujuan walaupun antara efektiftas dan produktifitas berjalan dan meiliki tujuan yang berbeda.

Berdasarkan latar

belakang yang dikemukakan di atas, masalah yang ingin diteliti dalam penelitian ini adalah
"Pengaruh Efektifitas dan Produktifitas Pramusaji atau Waiter/ss dalam Meningkatkan Pelayanan Hotel di Jember?"

Tujuan dari penelitian ini untuk mengetahui: "Mengkaji dan mengetahui pengaruh efektifitas dan produktifitas Pramusaji dalam meningkatkan pelayanan hotel di Jember".

Luaran dalam penelitian ini berupa desain dan pola kerja Pramusaji atau Waiter/ss. Sehingga Efektifitas dan Produktifitas pelayanan makanan dan minuman di hotel sesuai dengan keinginan tamu.

\section{METODE PENELITIAN}

Penelitian ini menggunakan teknis analisis data deskriptif kualitatif yaitu menggambarkan, menjelaskan dan menguraikan data yang terkumpul dari hasil penelitian dilapangan secara sistematis.

Agar tujuan dalam analisis Deskriptif kualitatif dapat tercapai dengan tepat, maka perlu didukung dengan analisis statisik data sebagai berikut :

1) Regresi Linier Berganda

Analisis yang digunakan untuk mengetahui besarnya pengaruh faktor Produktivitas dan Efektifitas kerja (variabel bebas) terhadap perputaran Kualitas Layanan Waiter/ss Hotel di Jember (variabel terikat) yang formulasinya sebagai berikut (Supranto, 2001:236).

$\mathrm{Y}=\mathrm{a}+\mathrm{b}_{1} \mathrm{X}_{1}+\mathrm{b}_{2} \mathrm{X}_{2}+\mathrm{e}$ Keterangan:

$\mathrm{Y}=$ Kualitas Layanan Waiter/ss

$\mathrm{X}_{1=}$ efektifitas

$\mathrm{X}_{1=}$ Produktifitas kerja 
$\mathrm{a}=$ Konstanta

$\mathrm{b}_{1} \ldots \mathrm{b}_{2}=$ Koefisien regresi

e =variabel gangguan

Analisis regresi dilakukan sebagai uji statistik dalam rangka mengetahui Faktor-Faktor yang Mempengaruhi Kualitas Layanan Waiter/ss Hotel di Jember.

2) Pengujian Terhadap Hipotesis

Penelitian yang Diajukan

Uji signifikansi komponen faktor penyebab (variabel bebas) terhadap Kualitas Layanan Waiter/ss Hotel di Jember (variabel terikat) secara simultan akan diuji dengan uji $\mathrm{F}$ (Ftest), sedangkan secara serentak akan diuji dengan uji statistik t ( $t$ test)

a). Pengujian dengan Uji F-Statistik

Uji F dimaksudkan untuk menguji hipotesis yang

berguna untuk menguji

signifikasi pengaruh variabel-

variabel independen secara

simultan terhadap variabel

dependen. Uji F-Statistik

digunakan secara serentak

terhadap Kualitas Layanan

Waiter/ss Hotel di Jember,

dengan tahapan sebagai

berikut:

(1). Menentukan nilai F-hitung

dengan rumus : (Rangkuti,

1997:165)

\begin{tabular}{|l|c|}
\hline \multirow{2}{*}{ Fhitung $=$} & $\mathrm{R}^{2} / \mathrm{K}$ \\
\cline { 2 - 2 } & $\left(1-\mathrm{R}^{2}\right)(\mathrm{N}-\mathrm{K}-1)$ \\
\hline
\end{tabular}

Keterangan :

$\mathrm{F} \quad=$ pengujian statistic

R2 = koefisien determinasi

$\mathrm{N}=$ jumlah sampel

$\mathrm{K}=$ jumlah variabel

(2). Menentukan Hipotesis

$\mathrm{Ho}=\sqcap \mathrm{i}=0 \quad$ Variabel-

variabel bebas secara simultan tidak mempunyai pengaruh yang signifikan terhadap variabel terikat.

$\mathrm{H}_{\mathrm{i}}=\square \mathrm{i} \square 0 \quad$ Variabel-
variabel bebas secara
simultan mempunyai
pengaruh yang signifikan
terhadap variabel terikat

(3). Menentukan tingkat signifikansi

Tingkat signifikansi yang

diharapkan adalah $\Pi=5 \%$ atau confident interfal $95 \%$

(4). Kriteria pengujian untuk pengujian dua sisi :

(a). Dengan membandingkan statistik hitung dengan statistik tabel

- Jika statistik Fhitung < statistik $\mathrm{F}_{\text {tabel, }}$, maka $\mathrm{H}_{\mathrm{o}}$ diterima

- Jika statistik Fhitung $>$ statistik $\mathrm{F}_{\text {tabel, }}$ maka $\mathrm{H}_{\mathrm{o}}$ ditolak

(b). Berdasarkan Probabilitas

- Jika probabilitas > 0,05, maka $\mathrm{H}_{\mathrm{o}}$ diterima

- Jika probabilitas < 0,05, maka $\mathrm{H}_{\mathrm{o}}$ ditolak

b). Pengujian dengan Uji t-Statistik Uji t-Statistik digunakan untuk menguji pengaruh dari komponen faktor yang mempengaruhi secara parsial terhadap Perputaran Kualitas Layanan Waiter/ss Hotel di Jember dengan tahapan sebagai berikut:

(1). Menentukan t-statistik dengan rumus : (Supranto, 2001 : 188)

$$
\mathrm{t}=\mathrm{b}-\mathrm{B}
$$

$$
\mathrm{Sb}
$$

Keterangan:

$\mathrm{b}=$ koefisien regresi parsial variabel

$\mathrm{B}=$ koefisien regresi parsial populasi

$\mathrm{Sb}=$ standar error koefisien regresi 
(2). Merumuskan Hipotesis

$$
\text { Ho }=\sqcap \mathrm{i}=0 \text { variabel }
$$
independen tidak mempunyai engaruh yang signifikan terhadap variabel dependen

$\mathrm{Hi}=\sqcap \mathrm{i} \quad \sqcap \quad 0$ variabel independen mempunyai pengaruh yang signifikan terhadap variabel dependen.

(3). Menentukan tingkat signifikan

Tingkat signifikansi yang diharapkan adalah 5\%, uji dua arah yaitu $t_{\text {tabel }}$ pada $\sqcap / 2=5 \%_{2}=0,025$ atau confident interval

(4). Kriteria pengujian untuk pengujian 2 sisi

(a). Dengan membandingkan statistik hitung dengan statistik tabel

- Jika statistik thitung < statistik $\mathrm{t}_{\text {tabel}}$, maka $\mathrm{H}_{\mathrm{o}}$ diterima

- Jika statistik thitung $>$ statistik $\mathrm{t}_{\text {tabel, }}$ maka $\mathrm{H}_{\mathrm{o}}$ ditolak

(b). Berdasarkan Probabilitas

- Jika probabilitas >0,05, maka $\mathrm{H}_{\mathrm{o}}$ diterima

- Jika probabilitas <0,05, maka $\mathrm{H}_{\mathrm{o}}$ ditolak

c. Tahap Pengambilan Kesimpulan

Pada tahap akhir penelitian maka perlu dilakukan penarikan kesimpulan dari hasil yang diteliti, yaitu penarikan kesimpulan yang didasarkan pada data-data dan formulasi yang telah dianalisis untuk memecahkan masalah yang dikemukakan. Dalam penarikan kesimpulan menggunakan metode deduktif, yaitu cara penarikan kesimpulan dari hal-hal yang bersifat umum berdasarkan ke halhal yang bersifat khusus. Setelah data yang dibutuhkan terkumpul kemudian dianalisis untuk menjawab permasalahan penelitian, yaitu bagaimana efektifitas dan produktifitas Pramusaji dalam meningkatkan pelayanan hotel di Jember.

\section{HASIL DAN PEMBAHASAN}

Efektivitas dan Produktifitas kerja Waiter / ss restoran yang ada didalam hotel di kota Jember dapat dilihat dari pemanfaatan waktu atas beban tugas yang dilaksanakannya. Hal ini mengacu pada standart operasional prosedur masing - masing hotel yang dibagi menjadi tiga bagian pola kerja yaitu Persiapan; Pelaksanaan tugas; Istirahat; dan Penyelesaian tugas. Ketepatan waktu waiter / ss di Jember dalam melaksanakan telah diatur dalam jadwal kerja masing - masing dengan beban kerja setiap harinya di restoran yang meliputi kegiatan pelayanan sarapan pagi bagi tamu hotel ( pelayanan Breakfast), pelayanan makan siang bagi tamu yang menginap maupun tamu dari luar hotel ( Pelayanan Lunch ), pelayanan makan malam bagi tamu yang menginap maupun tamu dari luar hotel ( Pelayanan Dinner ).

a. Ketrampilan Waiter/ss.

Merupakan kemampuan seorang waiter / ss untuk dapat melaksanakan tugas yang telah ditetapkan oleh pihak managemen, sehingga mencapai hasil yang diinginkan, penilaian kemampuan waiter / ss adalah kecakapan yang dimiliki oleh seorang waiter / ss yang diperoleh dari pengetahuan dan pengalaman.

b. Peralatan Kerja.

Waiter / ss memerlukan peralatan yang memadai dalam melaksanakan tugasnya untuk mencapai hasil kerja yang efektif dan produktif. Semakain baik peralatan yang digunakan, Produktivitas dan efektivitas yang akan 
tercapai, sehingga managemen hotel seharusnya memberikan fasiltas peralatan yang baik dan sesuai dengan kebutuhan kerja kepada waiter / ss .

c. Kapasitas restoran dan Beban kerja Waiter / ss.

Beban waiter / ss telah khususnya di restoran telah diatur dalam standart operasional prosedur (SOP) pelayanan yang ada di restoran yang meliputi Pelayanan Breakfast, Pelayanan Lunch, Pelayanan Dinner. Efektifitas dan Produktifitas Waiter / ss akan terlihat pada saat melaksanakan Standart pelayanan tersebut di restoran yang berkapasitas kecil, sedang dan besar.

d. Pengawasan.

Pengawasan terhadap waiter / ss dilakukan oleh managemen hotel melauiseorang supervisor dengan tugas untuk menimbulkan minat terhadap pekerjaannya, mendidik dan melatih bagaimana melakukan pekerjaannya, mengukur dan menilai hasil kerja, mengadakan koreksi - koreksi atas hasil kerja yang kurang tepat, sehingga tercapai efektifitas dan produktifitas kerja waiter / ss.

Setelah dilakukan pengujian statistik secara parsial (individu) dengan menggunakan uji t, maka analisis lebih lanjut dari hasil analisis regresi adalah:

\section{Pengaruh Efektifitas terhadap Kualitas layanan}

Hasil uji regresi menunjukkan variabel efektifitas berpengaruh positif dan signifikan terhadap kualitas layanan dengan koefisien 0,347. Hal ini berarti faktor efektifitas yang diukur melalui pramusaji atau waiter/ss menyelesaikan pekerjaan dengan baik dan benar, pramusaji atau waiter/ss melakukan pekerjaan sesuai dengan prosedur perusahaan, pramusaji atau waiter/ss menyelesaikan pekerjaan tepat waktu, pramusaji atau waiter/ss tidak menundanunda pekerjaan, pramusaji atau waiter/ss merasa puas dengan bidang pekerjaan yang digeluti saat ini, pramusaji atau waiter/ss menikmati setiap pekerjaan yang dikerjakan, hasil pekerjaan pramusaji atau waiter/ss diterima dengan baik oleh atasan dan rekan kerja, dan pekerjaan yang pramusaji atau waiter/ss selesaikan sesuai dengan target perusahaan.

\section{Pengaruh Produktifitas terhadap Kualitas layanan}

Hasil uji regresi menunjukkan variabel produktifitas berpengaruh positif dan signifikan terhadap kualitas layanan dengan koefisien 0,415. Hal ini berarti faktor produktifitas yang diukur melalui pramusaji atau waiter/ss mampu menyelesaikan sejumlah pekerjaan seperti yang ditetapkan perusahaan, pramusaji atau waiter/ss mampu menyelesaikan pekerjaan tepat waktu, pramusaji atau waiter/ss mampu menyelesaikan pekerjaan sesuai dengan prosedur yang ditetapkan perusahaan, pramusaji atau waiter/ss selalu meminimalisir kesalahan dalam bekerja, dan pramusaji atau waiter/ss mengerjakan pekerjaan dengan penuh tanggung jawab merupakan suatu faktor yang menentukan kualitas layanan pramusaji atau waiter/ss hotel di Jember.

\section{KESIMPULAN}

Berdasarkan uraian-uraian yang telah diungkapkan pada pembahasan, maka dapat diambil beberapa kesimpulan sebagai jawaban atas pokok permasalahan yang diajukan dalam penelitian ini, yaitu:

1. Efektifitas memiliki pengaruh signifikan terhadap kualitas layanan pramusaji atau waiter/ss hotel di Jember dengan koefisien 0,347 .

2. Produktifitas kerja memiliki pengaruh signifikan terhadap 
kualitas layanan pada Pramusaji atau waiter/ss hotel di Jember dengan koefisien 0,415 .

\section{DAFTAR PUSTAKA}

Agusnawar, A.Md.Par. 2002. Pengantar Operasional Kantor Depan Hotel. PT. Perca, Jakarta

Darsono Agustinus. 2001. Kantor Depan Hotel. PT.Gramedia Widiasarana Indonesia: Jakarta

Handoko T. Hadi. 2000. Manajemen Personalia Dan Sumberdaya Manusia. BPFE: Yogyakarta

Rangkuti, Freddy. 2001. Analisis SWOT Teknik Membedah Kasus Bisnis. Jakarta : Gramedia Pustaka Utama.

Soekadijo. R. G. 2000. Anatomi Pariwisata. Jakarta : PT Gramedia Pustaka Umum.

Soekresno, 2001. Manajemen Manajemen Food \& Beverage Service. PT. Gramedia Pustaka Utama

Sugiarto Endar, Ir, MM. 1996. Pengantar Akomodasi Dan Restoran. PT. Gramedia Pustaka Utama: Jakarta

Sugiharto, Endar \& Sulatiningrum. 2003. Pengantar Akomodasi dan Restoran.Gramedia Pustaka Utama

----------, Ir, MM. 1997. Operasional Kantor Depan. PT. Gramedia Pustaka Utama: Jakarta.

Swastha, Basu dan Irawan. 1997. Manajemen Pemasaran Modern. Edisi kelima, Yogyakarta : Liberty.

Tjiptono, Fandi. 2001. "Strategi Pemasaran". Edisi kedua, Yogyakarta : Andi
Wahab, Salah. 1997. Pemasaran Pariwisata. Jakarta : PT. Pradya Paramitha.

Yoeti, Oka. 1996. Pemasaran Pariwisata, Bandung : Angkasa Bandung. 